\title{
Experimental Study on Loading Capacity of Glued-Laminated Timber Arches Subjected to Vertical Concentrated Loads
}

\author{
Jiale Zhou, ${ }^{1}$ Chuanxi Li, ${ }^{1}$ Lu Ke $\mathbb{D}^{D},{ }^{1}$ Jun He, ${ }^{1,2}$ and Zhifeng Wang $\mathbb{D}^{3}$ \\ ${ }^{1}$ Key Laboratory of Bridge Engineering Safety Control by Department of Education, \\ Changsha University of Science and Technology, Changsha 410114, China \\ ${ }^{2}$ Institute for Infrastructure and Environment, Heriot-Watt University, Edinburgh, Currie EH14 4AS, UK \\ ${ }^{3}$ Department of Civil Engineering and Mechanics, Central South University of Forestry and Technology, Changsha 41004, China
}

Correspondence should be addressed to Lu Ke; clkelu@stu.csust.edu.cn and Zhifeng Wang; 13607431423@163.com

Received 27 December 2019; Revised 2 May 2020; Accepted 4 May 2020; Published 22 May 2020

Academic Editor: Jorge Branco

Copyright (c) 2020 Jiale Zhou et al. This is an open access article distributed under the Creative Commons Attribution License, which permits unrestricted use, distribution, and reproduction in any medium, provided the original work is properly cited.

\begin{abstract}
Glued-laminated timber arches are widely used in gymnasiums, bridges, and roof trusses. However, studies on their mechanical behaviours and design methods are still insufficient. This paper investigates the in-plane loading capacity of circular gluedlaminated timber arches made of Douglas fir. Experiments were conducted on four timber-arch models with different rise-to-span ratios under concentrated loads at mid-span and quarter-point locations. The structural responses, failure modes, and loading capacity of the timber arch specimens were obtained. The results show that the timber arches presented symmetric and antisymmetric deformation under mid-point and quarter-point loading conditions, respectively. The downward shifting of the neutral axis of the cross section was observed under mid-point loading condition, which contributes to higher loading capacity compared to that under quarter-point loading condition. The loading condition significantly affects the ultimate loads and the strain distribution in the cross section. Based on the design formula in current standards for timber structures, an equivalent beam-column method was introduced to estimate the loading capacity of the laminated timber arches under vertical concentrated loads. The moment amplification factor in the formula was compared and discussed, and the value provided in the National Design Specification for Wood Construction was recommended with acceptable accuracy.
\end{abstract}

\section{Introduction}

Glued-laminated (glulam) timber, which is made of glued layers of solid sawn lumber (timber lamellae), has numerous advantages such as high strength-to-weight ratio, excellent sustainability of sources, and superior designability [1]. The glued-laminated timber arches (glulam arches) have been widely used in many large-span structures, such as gymnasiums, bridges, and roof trusses [2-6]. However, the failure mechanism of glulam arches subject to external loads has not been sufficiently studied; many problems are still not well understood. It is of importance to understand the failure mechanism and design method for glulam arches under concentrated loads. The loading capacity of glulam arches is influenced by many factors, such as the rise-to-span ratio, lateral supports [7], creep of timber material [8], and reinforcement measures $[5,9-11]$.
Regarding the research on glulam arches, Rodman et al. [7] investigated the stability of glulam arches subjected to vertical distributed loads, finding that the rise-to-span ratio significantly affects the lateral buckling capacity of glulam arches. The lateral deformation is no longer crucial when sufficient lateral supports were provided. Zhu and Zhou [8] analyzed the influence of creep of the timber material on the loading capacity of glulam arches under full-span uniform loads through theoretical analysis; they revealed that the creep is the crucial factor affecting the loading capacity. Olsson [12] analyzed the influence of the load distribution on the internal forces in the glulam arches. The results show that the internal force distribution of glulam arches is sensitive to the load distribution. Kánnár et al. [13] analyzed the global bending and shear strength of timber structures, finding that the use of thinner lamella enables producing more homogeneous glulam structures. Ostrycharczyk and 
Malo [4] proposed a radial network pattern as a modification of a radial pattern to improve the performance of the network arch, especially the bending capacity of the arches. Rammer and Line [14] experimentally and analytically investigated the behavior of a full-scale three-hinged Tudor arch under service and ultimate loads. The results showed that the main arch structure was in an elastic state, and plastic deformation was only observed in the base connections.

Typical load patterns on circular arches include distributed vertical load and concentrated vertical load. For example, the main arch rib of an open-spandrel arch bridge was mainly subjected to concentrated loads from the pillars. The equivalent beam-column method was an effective method to calculate the loading capacity of the arches [15]. However, limited research has been performed on the failure mechanisms and loading capacity calculation methods for glulam arches under concentrated load. According to the equivalent beam-column design method, the arches, in many existing studies, are considered as columns subjected to both axial force and bending moment. The interaction formula was usually used to analyse their loading capacity. Currently, the main timber standards have provided interaction equations to calculate the loading capacity of glulam arches, such as GB/T 50708-2012 [16], National Design Specification for Wood Construction (NDS) [17], and Eurocode 5 [18]. However, the formulas of moment amplification factors, which describe the second-order effect of axial force, are quite different in these standards. Thus, more studies are needed to verify which moment amplification factor calculation method is the most suitable one for evaluating the loading capacity of glulam arches.

The objective of this paper is to investigate the failure mechanisms and loading capacity of glulam arches subjected to vertical concentrated loads. First, the structural responses, failure modes, and loading capacity of the timber-arch specimens were obtained through experimental investigation. Then, based on the design formula in current timber structure standards, an equivalent beam-column method was introduced to estimate the loading capacity of laminated timber arches under mid-span and quarter-span load conditions. Finally, based on the experimental results, the moment amplification factor calculation methods were compared and discussed to propose some recommendations.

\section{Materials and Specimens}

2.1. Materials. In this study, North American Douglas fir lumbers (botanical name: Pseudotsuga menziesii Franco) (Western Wood Structures Inc., Tualatin, OR, USA) and phenol resorcinol formaldehyde resin adhesive (Nanjing Skybamboo Science \& Technology Industry Co., Ltd, Nanjing, China) were used to fabricate the timber arches.

According to GB50005-2017 [19], the Douglas fir lumber was selected according to the results of visual stress grading. The quality grade of the lumber materials is $I_{c}$. The tension and compression tests of timber were conducted according to the Standard for Test Methods of Timber Structures [20].
The elastic modulus $(E)$, tensile ultimate strength $\left(f_{\mathrm{t}}\right)$, and compressive strength $\left(f_{\mathrm{c}}\right)$ in the parallel-to-grain direction were obtained. Each test includes 10 samples. The material properties of Douglas fir timber are listed in Table 1. The mechanical properties of timber are influenced by many factors, such as the growth region and humidity. Thus, the dispersion of the mechanical properties for the timber is acceptable. The representative stress-strain relationships for the timber are shown in Figure 1. The tensile behaviour is in a perfect elastic stage. A bilinear relationship was adopted to describe the compressive behaviour. $\varepsilon_{\mathrm{cy}}, \varepsilon_{\mathrm{cu}}$, and $\varepsilon_{\mathrm{tu}}$ represent the compressive yield strain, compressive ultimate strain, and tensile ultimate strain, respectively. The moisture content range of the lumber is between $13.00 \%$ and $13.58 \%$, with an average value of $13.28 \%$, which is less than the NDS recommended value $16 \%$ for dry service conditions. The mean density of timber is $528 \mathrm{~kg} / \mathrm{m}^{3}$.

The phenol resorcinol formaldehyde adhesive (PRF) was used for the lamination, and the glue consumption was 250 to $300 \mathrm{~g}$ per square meter. The mechanical properties of the adhesive, provided by the manufacturer, are listed in Table 1.

2.2. Specimens Preparation. To investigate the loading capacity and mechanical response of glued-laminated timber arches, four timber arches were fabricated and tested. Previous studies [21] indicated that the ratio between bending moments and axial forces in the arch depends predominantly on the loading conditions and rise-to-span ratio of the arch. Thus, the major design parameters of the specimens include (1) the rise-to-span ratio and (2) the loading condition. The radius and cross-sectional (rectangle) dimensions of all specimens were $3000 \mathrm{~mm}$ and $56 \mathrm{~mm} \times 140 \mathrm{~mm}$, respectively.

The fabrication procedure of glued-laminated timber arches includes grading, finger joining, gluing, and bending forming processes. First, the desired length of lamellae was obtained through finger joining method, and the lamellae were bent by a work bench to develop the circular profile. Then, the glulam arches were made of 9 lamellae glued together and were bent on the work bench again. The pressure applied at lamination was maintained around $1 \mathrm{MPa}$ during the 24-hour curing procedure. Final, the laminated arches were cut into specimens with the required rise-span ratio. It is worth noting that the $45 \mathrm{~mm}$ thick lamellae in the original design are hard to be bent into a circular arch profile. Therefore, the thickness of lamellae was thinned from $45 \mathrm{~mm}$ to $15.5 \mathrm{~mm}$. The radius and crosssectional dimensions of all specimens were identical for fabrication; the dimensions of the specimens are shown in Figure 2.

In total, 4 glulam arches were fabricated and tested. The specimens were labelled alphanumerically depending on the rise-to-span ratio and loading condition. " $\mathrm{C}$ " and "Q" represent mid-point loading and quarter-point loading conditions, respectively. The numbers following " $R$ " represent the rise-to-span ratio of the arch. For example, "R1/6C" denotes a timber-arch specimen under the mid-point load, with a rise-to-span ratio of $1 / 6$ (Table 2 ). 
TABle 1: Material properties of timber and PRF.

\begin{tabular}{|c|c|c|c|c|}
\hline Materials & & $f_{\mathrm{t}}(\mathrm{MPa})$ & $f_{\mathrm{c}}(\mathrm{MPa})$ & $E(\mathrm{MPa})$ \\
\hline \multirow{3}{*}{ Douglas timber } & Mean value & 83.7 & 40.0 & 9804.3 \\
\hline & Standard deviation & 4.52 & 3.78 & 1429.6 \\
\hline & $\mathrm{COV}^{\mathrm{a}}$ & $5.5 \%$ & $9.47 \%$ & $14.5 \%$ \\
\hline Epoxy resin & Mean value & 9.2 & 70.0 & 3320 \\
\hline
\end{tabular}

Note. ${ }^{a}$ coefficient of variation.

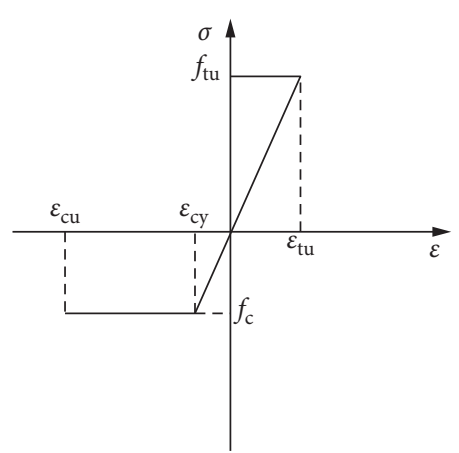

FIGURE 1: Stress-strain relationships of glulam timber.

\section{Experimental Program}

3.1. Experimental Setup. The specimens were tested using hydraulic jacks (Hailing, Taizhou, China) with a loading capacity of $100 \mathrm{kN}$. The specimens were connected to the support through a hinge at the arch foot. The horizontal displacement of the arch foot was limited by the reaction frame and tension bar connecting two supports. The test setups for the timber arches are shown in Figure 3. In the tests, four pairs of lateral supports were set at $L / 5$ ( $L$ is the span), $2 L / 5,3 L / 5$, and $4 L / 5$ to prevent out-of-plane deformation during the loading process.

3.2. Loading Procedure and Measurement. The measurement systems for the displacement and strain are shown in Figure 2. The local displacement was measured using six electronic dial indicators. Three electronic dial indicators $(\# 2$, \#3, and \#4) were, respectively, located at $L / 4, L / 2$, and $3 L / 4$ to measure the vertical displacements. The other two electronic dial indicators (\#1 and \#5) were installed to measure the horizontal deformation of the specimens caused by the rotation of the arch feet. The electronic dial indicator \#6 was set at the arch crown to capture the out-of-plane deformation. Rosette strain gauges were installed on the surfaces of sections at $0 L$ (left support), $L / 4, L / 2,3 L / 4$, and $L$ (right support) to capture the strain state. A total of eight strain gauges along the arch axis were arranged at each section. In all, 40 strain gauges were applied to each specimen. The strain data were collected by the TST3826 static data acquisition system.

During the test, a concentrated load was monotonically applied to the specimens through a hydraulic jack. The magnitude of the applied force was measured by a load cell. A multistep loading procedure was performed during the tests. When the load was less than $70 \%$ of the ultimate load $\left(P_{\text {ult }}\right)$ as predicted according to GB/T 50708-2012, the load was applied at a rate of $4 \mathrm{kN}$ per step. After the load reached $70 \% P_{\text {ult }}$, the load was increased at a rate of $2 \mathrm{kN}$ per step, until the failure of specimen.

\section{Results and Discussions}

4.1. Failure Characteristics. Previous research [22] indicated that the unreinforced laminated members subjected to bending moment alone or in combination of axial compression and bending actions failed in tension mode with a brittle manner. In this study, all the laminated arches exhibited the tension failure mode, except Q1/6-C, as shown in Figure 4. The failure positions of each specimen were located at the cross section of loading area, due to the bending moment of cross section. Specifically, the failure positions of specimens were located in the mid-span section under mid-span point load, while in quarter-span section under mid-point load.

In general, under the mid-point load conditions, the wood fibres in the mid-span tension zone fractured, which resulted in the failure of the specimen. In contrast, under quarter load conditions, the failure position of the specimens (except R1/6-Q) was the tension zone of the loading section. For specimen R1/6-C, obvious plastic deformation was observed in the compression zone of the mid-span section, as shown in Figure 4(a). Taking specimen R1/5-C as an example, the typic failure process was described as follows. First, when the compressive stress at the mid-span cross section reached the compression strength, obvious compressive plastic deformation was observed. With the increase of the applied load, the tensile stress at the mid-span cross section reached the tensile strength, and tension failure was observed at mid-span section. Then, the applied load dropped continually and obvious upward deformations at the position of $L / 4$ and $3 L / 4$ were observed. For the specimen $\mathrm{R} 1 / 5-\mathrm{Q}$, the cause of failure was the tension failure in the bottom layer at the loading position. It should be noted that, for specimen $\mathrm{R} 1 / 6-\mathrm{Q}$, tensile cracks in the bottom layer, which extended into the middle layers, resulted in the failure of the specimen, as shown in Figure 4(c). This is due to a manufacturing defect of the drilling holes at the arch foot section, which leads to a weakening of cross section.

4.2. Load-Displacement Response. The load $(P)$ displacement $(v)$ curves for all specimens are illustrated in Figure 5. The measured displacements at \#3 and \#4 dial indicators were selected to describe the $v-P$ curves for the mid-point and 


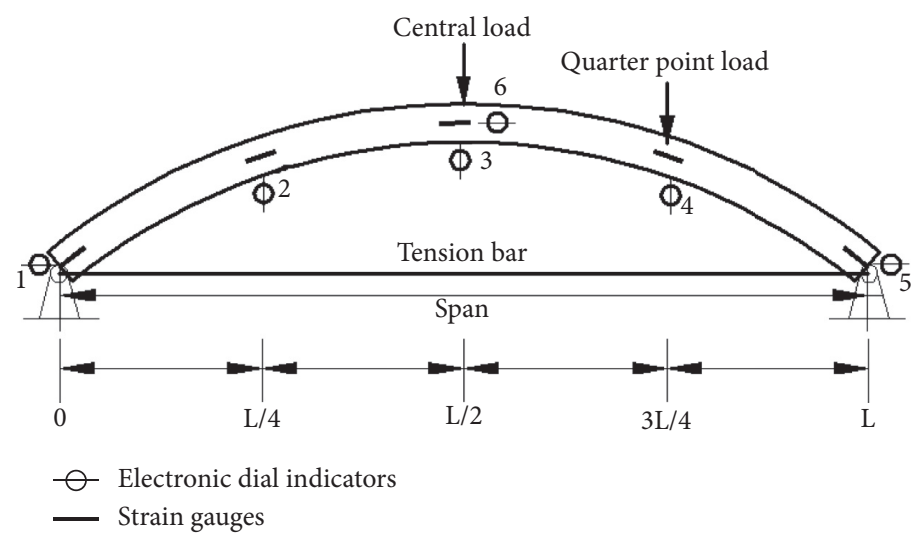

(a)

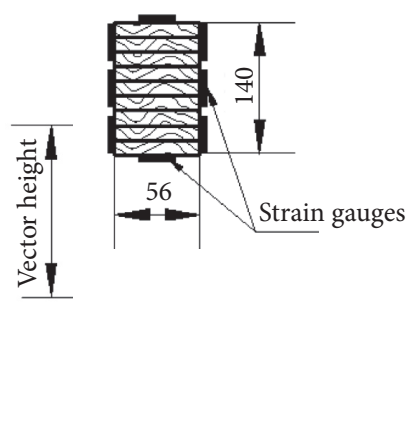

(b)

Figure 2: Schematic drawing of specimens (unit: $\mathrm{mm}$ ): (a) vertical view and (b) cross section.

TABLe 2: Specimen details.

\begin{tabular}{|c|c|c|c|c|c|c|c|}
\hline $\begin{array}{l}\text { Circle } \\
\text { radius }\end{array}$ & $\begin{array}{l}\text { Specimen } \\
\text { number }\end{array}$ & $\begin{array}{l}\text { Height } \\
(\mathrm{m})\end{array}$ & $\begin{array}{c}\text { Span } \\
(\mathrm{m})\end{array}$ & $\begin{array}{l}\text { Rise-to-span } \\
\text { ratio }\end{array}$ & $\begin{array}{c}\text { Loading } \\
\text { conditions }\end{array}$ & $\begin{array}{l}\text { Sectional dimension } \\
(\mathrm{mm})\end{array}$ & Moisture content (\%) \\
\hline \multirow{4}{*}{$R=3 \mathrm{~m}$} & $\mathrm{R} 1 / 6-\mathrm{C}$ & 0.6 & 3.6 & $1 / 6$ & Mid-point load & \multirow{4}{*}{$56 \times 140$} & \multirow{4}{*}{13.28} \\
\hline & $\mathrm{R} 1 / 6-\mathrm{Q}$ & 0.6 & 3.6 & $1 / 6$ & \multirow{3}{*}{$\begin{array}{c}\text { load } \\
\text { Mid-point load } \\
\text { Quarter-point } \\
\text { load }\end{array}$} & & \\
\hline & $\mathrm{R} 1 / 5-\mathrm{C}$ & 0.85 & 4.2 & $1 / 5$ & & & \\
\hline & $\mathrm{R} 1 / 5-\mathrm{Q}$ & 0.85 & 4.2 & $1 / 5$ & & & \\
\hline
\end{tabular}

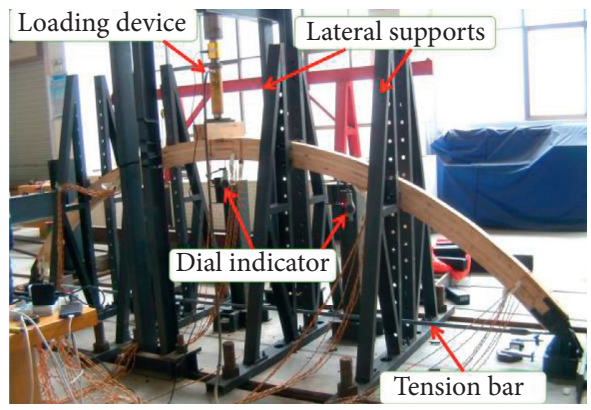

(a)

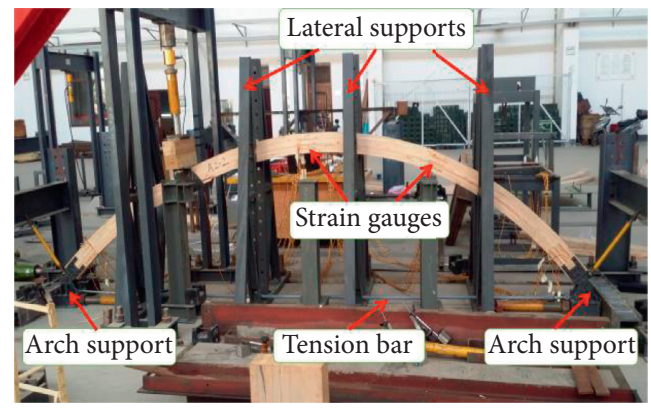

(b)

Figure 3: Experimental setup: (a) mid-point and (b) quarter-point loading conditions.

quarter-point loading conditions. The $v-P$ curves can be divided into two stages: elastic and elastoplastic stages. All of these $v-P$ curves are in linear relation at the elastic stage. The $v-P$ curves exhibited a nonlinear relation with rapid increase of displacement at the elastoplastic stage. When the applied load reached the ultimate value, the specimens failed in a brittle manner.

The curves of R1/6-Q and R1/5-Q enter the elastoplastic stage when the load reaches $12 \mathrm{kN}$. However, the curves of $\mathrm{R} 1 / 6-\mathrm{C}$ and $\mathrm{R} 1 / 5-\mathrm{C}$ exhibit a nonlinear relationship when the load reaches $14 \mathrm{kN}$. The ultimate load and corresponding displacement for the specimens under quarter-point load conditions are lower than those for the specimens under a mid-point load condition. From Figure 5, it can be conducted that the $v-P$ curves of all specimens have no obvious descending branches.

The applied load and corresponding displacements at the elastic state and ultimate state and failure modes of all specimen are illustrated in Table 3 . The elastic limit load $\left(P_{\mathrm{e}}\right)$ under the mid-point load is $14 \mathrm{kN}$, which is 1.17 times of that $(12 \mathrm{kN})$ under quarter-point load. While the ultimate load $\left(P_{\text {ult }}\right)$ under the mid-point load is 1.13-1.34 times of that under the quarter-point load. It can be conducted that the specimens under quarter-point load exhibited plastic behavior earlier than the specimens under the mid-point load did. The loading condition has a slight effect on the elastic limit loads $\left(P_{\mathrm{e}}\right)$, but has a significant effect on the ultimate loads $\left(P_{\text {ult }}\right)$. The main reason is that all the specimens failed 


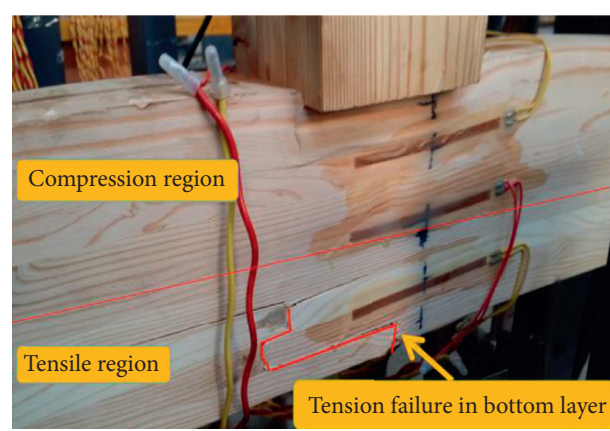

(a)

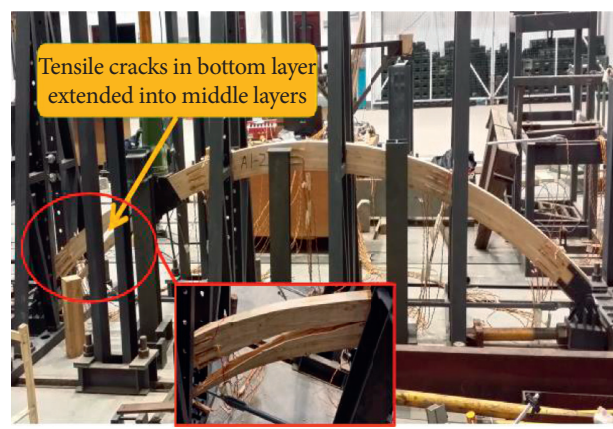

(c)

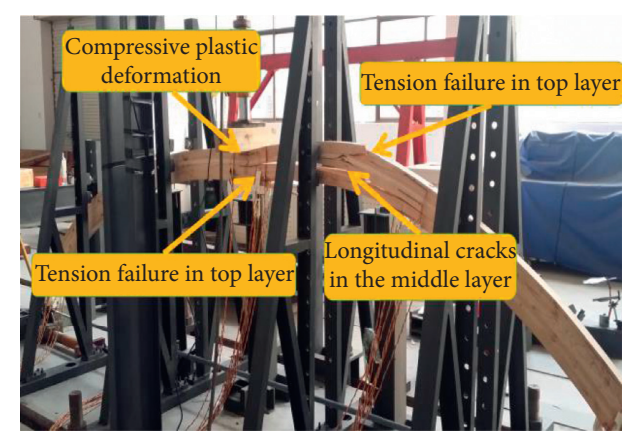

(b)

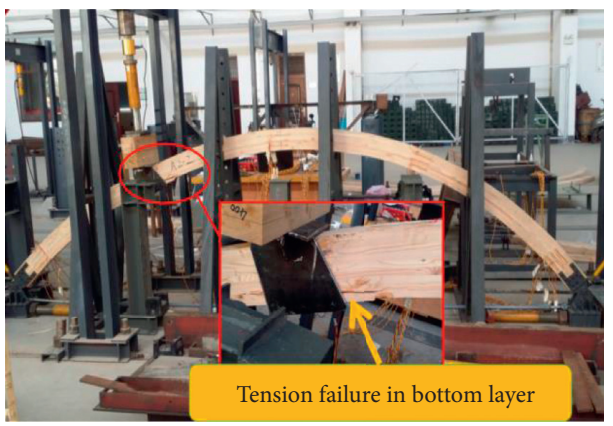

(d)

Figure 4: Failure modes of the specimen. (a) Specimen R1/6-C. (b) Specimen R1/5-C. (c) Specimen R1/6-Q. (d) Specimen R1/5-Q.

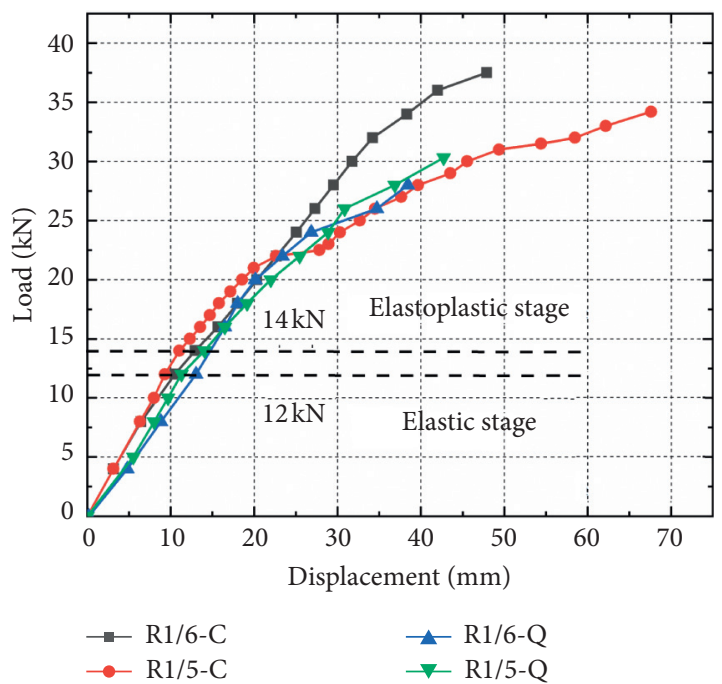

FIgURE 5: Load-displacement curves of glulam arch specimens.

in tension mode due to bending moments. Thus, the glulam arches under quarter load displayed larger moments than the arches under the mid-point load.

All the specimens presented an obvious deflection at the loading section. At the ultimate state, the maximum deformations are $38.45-67.59 \mathrm{~mm}$, which is between $1 / 62$ and $1 / 98$ of the span. The obvious deformation and cracks were observed at the ultimate state for each specimen.

Representative experimental vertical displacements under different load levels are given in Figure 6. The measured values of $\# 2, \# 3$, and \#4 dial indicators were selected to describe the vertical displacement distributions. In the figure, the downward and upward displacements are given negative and positive values, respectively. The results show that the maximum deformation locates at the loading section. The specimens under the mid-point load exhibited symmetric deformation. In contrast, the specimens under quarter-point load exhibited antisymmetric deformation.

4.3. Load-Strain Relationships. The relationships of applied load and longitudinal strain of each specimen are illustrated in Figure 7. The measured values of strain gauges located in mid-span and $3 L / 4$ sections were selected to describe the load-strain relationships. The compressive and tensile strains are defined as negative and positive values, respectively. According to the limit strain analysis method, the cross section fractured when the fibres in the tension region reached their tensile ultimate strain, and then the whole specimen failed due to tension fracture.

Under the mid-point load conditions, the tensile and compressive strains exhibited a linear distribution at the early stage of loading, and the strains were satisfied with the plane section assumption. With the increase of loading, the nonlinearity of compressive strain became more obvious. The neutral axis began to shift toward the tension region under the mid-point load. The offsets of R1/5-C and R16-C were approximately 0.8 and $2 \mathrm{~cm}$, respectively, which is between $h / 18$ and $h / 7$ ( $h$ is the height of the cross section), as shown in Figures 7(a) and 7(c). The reasons can be explained as follows. According to the constitutive relation of materials as shown in Figure 1, the compressive stress did not increase anymore when the compressive strain came to compressive yield strain $\left(\varepsilon_{\mathrm{cy}}\right)$. However, the tensile limit strength $\left(f_{\mathrm{tu}}\right)$ 
TABLE 3: Experimental results.

\begin{tabular}{|c|c|c|c|c|c|}
\hline \multirow{2}{*}{ Specimen number } & \multicolumn{2}{|c|}{ Elastic limit state } & \multicolumn{2}{|c|}{ Ultimate capacity state } & \multirow{2}{*}{ Failure mode } \\
\hline & $P_{\mathrm{e}}(\mathrm{kN})$ & $D_{\mathrm{e}}(\mathrm{mm})$ & $P_{\text {ult }}(\mathrm{kN})$ & $D_{\max }(\mathrm{mm})$ & \\
\hline $\mathrm{R} 1 / 6-\mathrm{C}$ & 14.00 & 12.92 & 37.50 & 47.88 & $\mathrm{a}$ \\
\hline $\mathrm{R} 1 / 6-\mathrm{Q}$ & 12.00 & 13.04 & 28.00 & 38.45 & c \\
\hline $\mathrm{R} 1 / 5-\mathrm{C}$ & 14.00 & 11.04 & 34.20 & 67.59 & $\mathrm{a}$ \\
\hline $\mathrm{R} 1 / 5-\mathrm{Q}$ & 12.00 & 11.31 & 30.30 & 42.74 & $\mathrm{~b}$ \\
\hline
\end{tabular}

Note: Failure modes: $\mathrm{a}=$ tension failure at mid-span section, $\mathrm{b}=$ tension failure at quarter-span section (loading section), and $\mathrm{c}=$ tearing failure at arch foot.

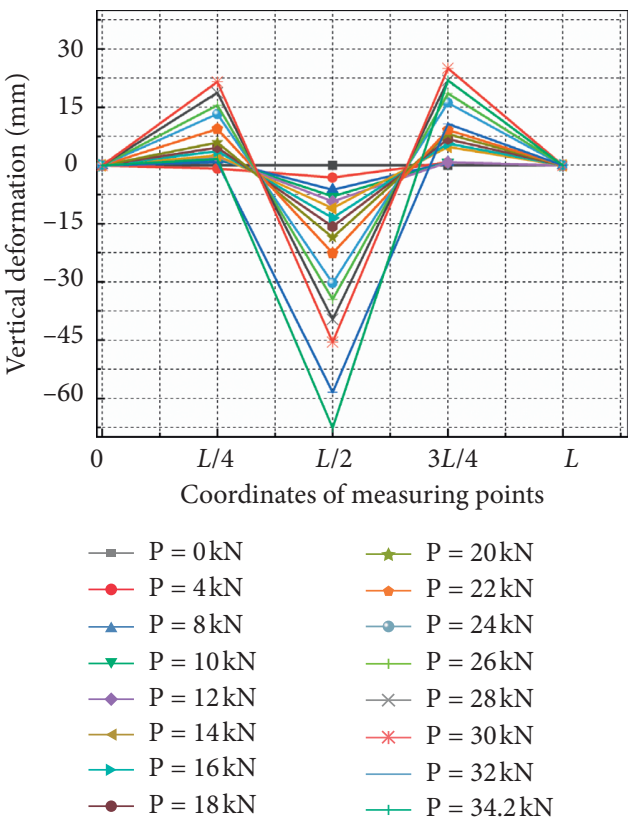

(a)

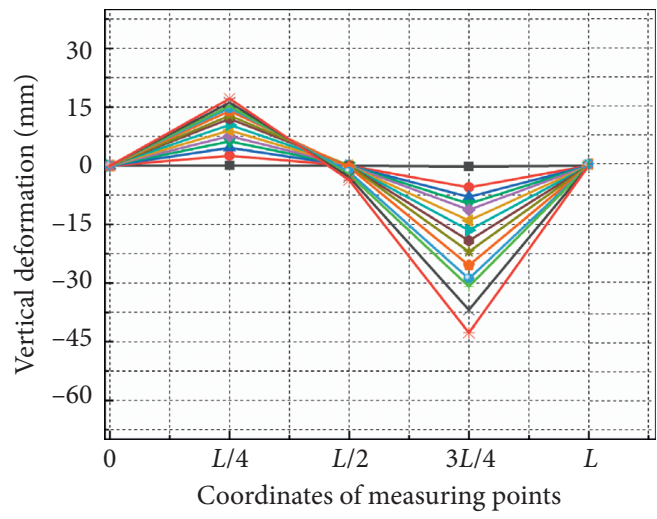

$$
\begin{array}{ll}
\multimap \mathrm{P}=0 \mathrm{kN} & \rightarrow \mathrm{P}=18 \mathrm{kN} \\
\rightarrow \mathrm{P}=5 \mathrm{kN} & \rightarrow \mathrm{P}=20 \mathrm{kN} \\
\multimap \mathrm{P}=8 \mathrm{kN} & \rightarrow \mathrm{P}=22 \mathrm{kN} \\
\rightarrow \mathrm{P}=10 \mathrm{kN} & \rightarrow \mathrm{P}=24 \mathrm{kN} \\
\multimap \mathrm{P}=12 \mathrm{kN} & \rightarrow \mathrm{P}=26 \mathrm{kN} \\
\multimap \mathrm{P}=14 \mathrm{kN} & \rightarrow \mathrm{P}=28 \mathrm{kN} \\
\rightarrow \mathrm{P}=16 \mathrm{kN} & \rightarrow \mathrm{P}=30.3 \mathrm{kN}
\end{array}
$$

(b)

FiguRE 6: Experimental vertical displacement distributions: (a) under mid-point and (b) quarter-point loads.

was larger than the compressive strength $\left(f_{c}\right)$; the tensile stress continued to increase before the tensile strain reaching the tensile ultimate strain $\left(\varepsilon_{\text {tu }}\right)$. Based on the stress equilibrium condition, the depth of the compression region increased and the neutral axis shifted downward. Finally, when the load reached $P_{\text {ult }}$, the compressive and tensile strain exceeded their limit value.

Under the quarter-point load conditions, the shifting of the neutral axis toward the tension region was not observed, as shown in Figures 7(b) and 7(d). The reason is that the member with larger bending moment resulted in a more rapid increase of tensile and compressive strain, and a decrease of loading-carrying capacity. The tensile strain of specimens subjected to a quarter-point load was higher than that of specimens subjected to a mid-point load.

It is worth noting that the compressive and tensile strain of $\mathrm{R} 1 / 6-\mathrm{Q}$ were $3738 \mu \varepsilon$ and $5531 \mu \varepsilon$, respectively, when the load reached the ultimate load. The specimen R1/ 6- $\mathrm{Q}$ was destroyed before the compressive and tensile stress reached its limit $\left(\varepsilon_{\mathrm{cu}}\right.$ and $\left.\varepsilon_{\mathrm{tu}}\right)$. This also indicates that the failure mode of specimens R1/6-Q was not tension failure at $3 L / 4$ section. Therefore, the strain distributions of the loading cross section are significantly influenced by the load condition.

\section{Theoretical Analysis}

5.1. Equivalent Beam-Column Method. Based on the equivalent beam-column method [15], the arches under axial compression and bending actions are regarded as eccentric columns. Then, the internal forces of the corresponding cross section can be obtained by interaction formula. Lastly, the critical load of arches can be calculated according to the relationship between the load and internal force. To simplify the calculation of loading capacity of glulam arches, we assume that:

(1) There is no slip between adjacent lamellae;

(2) Timber is an anisotropy material, and the failure of specimens is determined by the strength parallel to the grain;

(3) The initial defects, such as inner stress due to bending of lamellae and geometric imperfections, were ignored. 


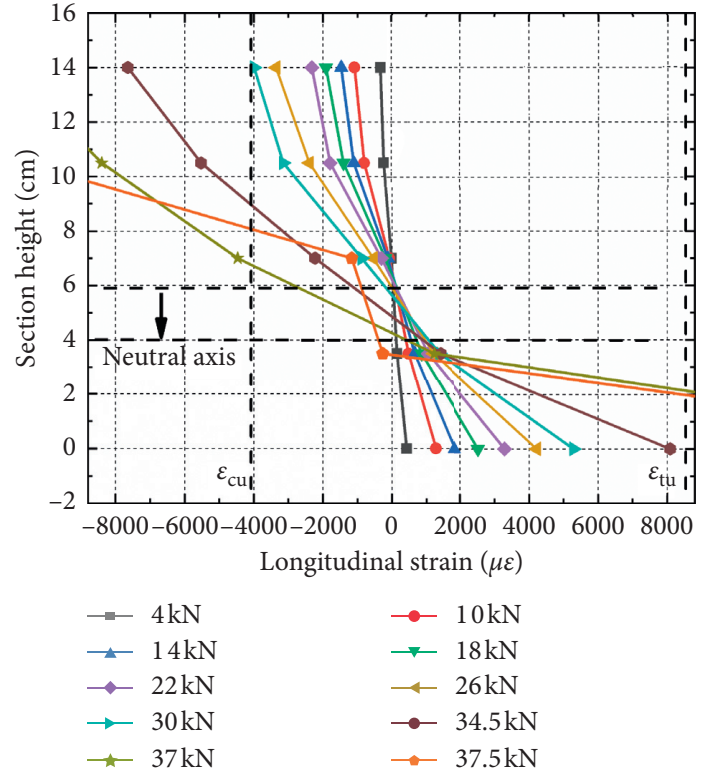

(a)

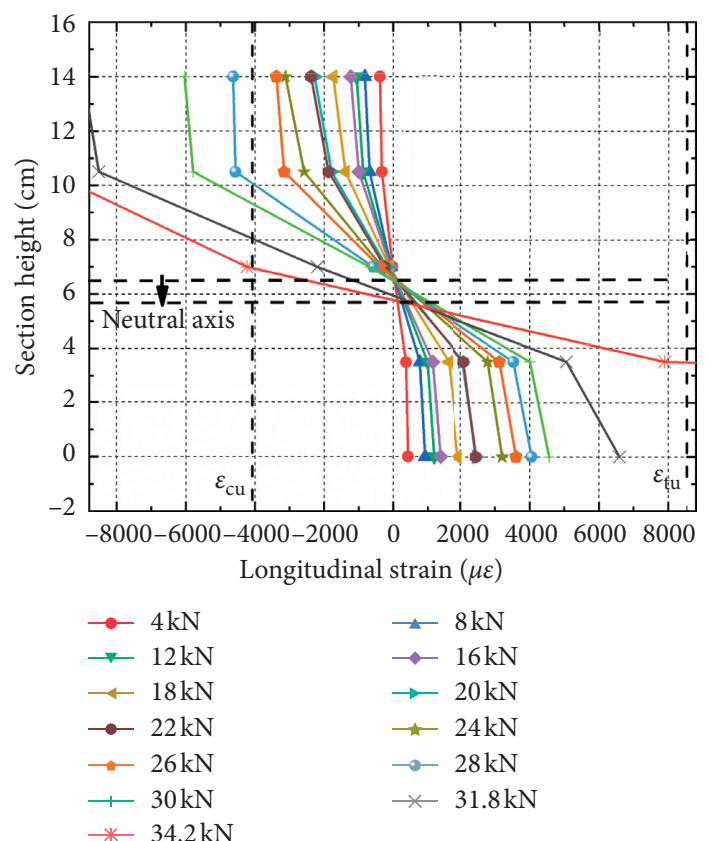

(c)

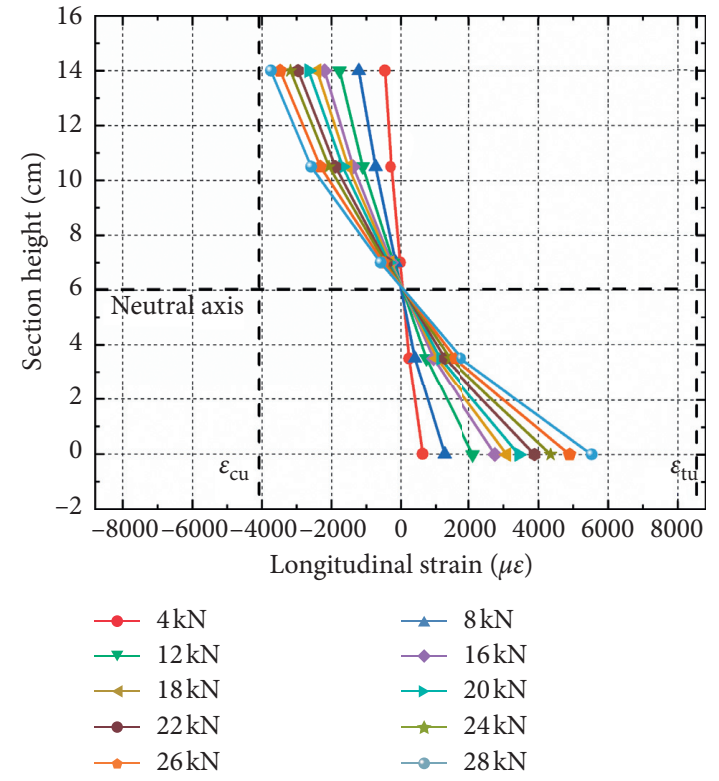

(b)
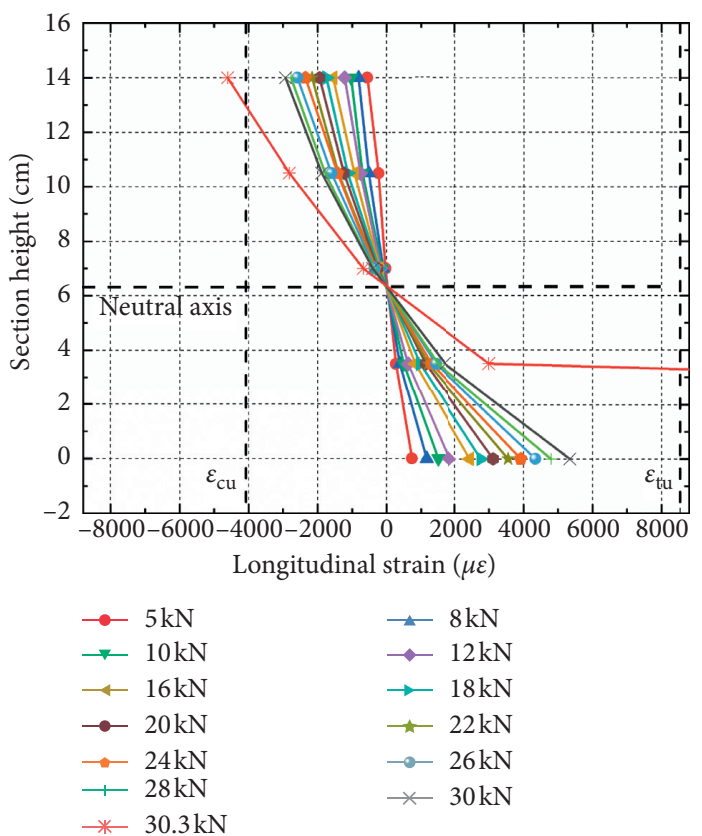

(d)

Figure 7: Section stress distributions of specimens. (a) Specimen R1/6-C. (b) Specimen R1/6-Q. (c) Specimen R1/5-C. (d) Specimen R1/5-Q.

By first-order analysis, the relationship between the applied load and the internal forces at the cross section can be established. Under mid-point load, the internal forces of the mid-span section are

$$
\begin{aligned}
& M=\frac{P l}{16}, \\
& N=\frac{5 P l}{16 f},
\end{aligned}
$$

where $P$ is the applied load; $l$ and $f$ are the span and height of arches, respectively.

Under quarter-point load, the internal forces at quarterspan section are

$$
\begin{aligned}
& M=\frac{21 P l}{128} \\
& N=\frac{1}{\sqrt{4 f^{2}+l^{2}}} \cdot\left(\frac{3 P f}{2}+\frac{15 P l^{2}}{32 f}\right) .
\end{aligned}
$$


5.2. Discussions on the Load Bearing Capacity of Glulam Arch. In current standards, such as GB/T 50708-2012 [16] and NDS [17], the design formula of glulam arches is based on the bilinear interaction relationship between the axial force $(N)$ and bending moment $(M)$ at a specific cross section of the arches. The interaction formulas presented in the above standards were adopted to estimate the loading capacity of glulam arches.

The interaction formulae recommended in NDS [17] are as follows:

$$
\begin{aligned}
\left(\frac{N}{A_{n} f_{\mathrm{c}}}\right)^{2}+\frac{M}{W f_{m}\left[1-\left(N / A_{n} f_{\mathrm{cE}}\right)\right]} & \leq 1, \\
f_{\mathrm{cE}} & =\frac{0.47 E}{\left(l_{0} / h\right)^{2}}, \\
A_{n} & =b * h, \\
W & =\frac{b h^{2}}{6},
\end{aligned}
$$

where $N$ and $M$ are the axial force and bending moment calculated by equations (1)-(4), respectively. $A_{n}$ and $W$ are the area of cross-section and the sectional resistance moment, respectively, calculated by equations (7) and (8), respectively. $b$ and $h$ refer to the width and height of crosssection. $E$ is the modulus of elasticity. $l_{0}$ is the effective length of the compression member. For hinge-supported arches, $l_{0}$ is equal to arc-length. $f_{\mathrm{cE}}$ is the compressive critical buckling strength. $1-\left(N / A_{n} f_{\mathrm{cE}}\right)$ is the moment amplification factor to consider the second-order effect. According to the compressive and tensile strength [23], the bending strength parallel to the grain $f_{m}$ is

$$
f_{m}=f_{c} \frac{3\left(f_{\mathrm{t}} / f_{\mathrm{c}}\right)-1}{\left(f_{\mathrm{t}} / f_{\mathrm{c}}\right)+1} \text {. }
$$

The interaction formula recommended in [16] is similar to equation (5), but the main difference is

$$
f_{\mathrm{cE}}=\frac{0.822 E_{\mathrm{min}}^{\prime}}{\left(l_{0} / h\right)^{2}},
$$

here $E_{\text {min }}^{\prime}$ is modified modulus of elasticity. Based on the Load and Resistance Factor Design method in [18], $E_{\min }^{\prime}$ is calculated as

$$
E_{\min }^{\prime}=C_{\mathrm{t}} \cdot C_{\mathrm{M}} \cdot K_{\mathrm{F}} \cdot \varphi \cdot E_{\min },
$$

where $C_{\mathrm{t}}$ and $C_{\mathrm{M}}$ are the temperature factor and wet service factor, which are taken as 1.0. $K_{\mathrm{F}}$ is the format conversion factor, 1.76. $\varphi$ is the resistance factor, and $0.85 . E_{\min }$ is the reference value of elastic modulus, $5447 \mathrm{MPa}$.

The elastic load $\left(P_{\mathrm{e}}\right)$ under the mid-point load is higher than that under quarter-point load. According to equations (1)-(4), under the same applied load, the bending moment at the quarter-span section under quarter-point load is larger than that at the mid-span section under central-point load. Therefore, the elastic load $\left(P_{\mathrm{e}}\right)$ of specimens is higher for the central load position. The experimental and theoretical results of loading capacity for all specimens are listed in Table $4 . P_{U, 1}^{C}$
TABle 4: Theoretical and experimental results of load bearing capacity.

\begin{tabular}{lccccc}
\hline \multirow{2}{*}{ Specimen number } & \multicolumn{5}{c}{ Loading capacity $(\mathrm{kN})$} \\
& $P_{U, 1}^{C}$ & $P_{U, 2}^{C}$ & $P_{U}^{T}$ & $\left(P_{U, 1}^{C} / P_{U}^{T}\right)$ & $\left(P_{U, 2}^{C} / P_{U}^{T}\right)$ \\
\hline $\mathrm{R} 1 / 6-\mathrm{C}$ & 25.18 & 36.59 & 37.50 & 0.67 & 0.98 \\
$\mathrm{R} 1 / 6-\mathrm{Q}$ & 18.22 & 26.48 & 28.00 & 0.65 & 0.95 \\
$\mathrm{R} 1 / 5-\mathrm{C}$ & 21.13 & 30.72 & 34.20 & 0.62 & 0.90 \\
$\mathrm{R} 1 / 5-\mathrm{Q}$ & 15.89 & 23.09 & 30.30 & 0.52 & 0.76 \\
\hline
\end{tabular}

and $P_{U, 2}^{C}$ are the theoretical values of loading capacity calculated by the formula in $[16,17]$, respectively. The values of materials properties were taken as the mean values in Table 1. $P_{U}^{T}$ is the experimental value of test specimen. The theoretical values of $P_{U, 1}^{C}$ are 0.52 to 0.67 times of $P_{U}^{T}$, while the $P_{U, 2}^{C}$ is 0.76 to 0.98 times of $P_{U}^{T}$. The results show that the design formula of GB/T 50708-2012 underestimates the loading capacity of glulam arches under mid-point and quarter-point load; the formula in NDS can predict the loading capacity more accurately. The values of $\left(P_{U, 2}^{C} / P_{U}^{T}\right)$ for specimens $\mathrm{R} 1 / 5-\mathrm{C}$ and R1-5-Q are 0.9 and 0.76 , respectively. With the increase of bending moment at the loading position, the value of $\left(P_{U, 2}^{C} / P_{U}^{T}\right)$ decreases gradually. Thus, the design formulas in NDS can be used to evaluate the loading capacity of glulam arches with acceptable accuracy.

The main reason is that the moment amplification factor in NDS is a variable that depended on the bending stress and modulus of elasticity. However, the moment amplification factor in GB/T 50708-2012 is a fixed value, which is the lower limit value of that in NDS.

\section{Conclusions}

This study investigates the in-plane loading capacity of glued-laminated arches subjected to vertical concentrated loads. A total of 4 specimens with different rise-to-span ratios and loading conditions were designed to study their mechanical properties, including structural response, failure modes, and loading capacity. Furthermore, based on equivalent beam-column method, the calculated method of loading capacity was discussed. The following conclusions can be drawn:

(1) The loading condition slightly affects the elastic limit loads but significantly affects the ultimate loads of glulam arches. The loading capacity of the arches under the mid-point load is 1.13-1.34 times of that under quarter-point load. The glulam arches under mid-point load display larger moment under ultimate load than the arches under quarter-point load do.

(2) The load-displacement relationships for all the glulam arches have elastic and elastoplastic stages, and they contain no obvious descending branches. All of the glued-laminated arch specimens mainly failed due to tension failure in a brittle manner. The specimens, respectively, presented symmetric and antisymmetric deformation under mid-point 
loading and quarter-point loading conditions. At the ultimate state, obvious deflections were observed at the loading section, which is between 1/62 and 1/98 of the span.

(3) The strain distribution strongly depends on the load condition. Under mid-point loading conditions, the neutral axis shifting toward the tension region in the cross section at the loading position was observed, and the maximum offsets of the neutral axis were 1/18 and $1 / 7$ of the cross section height. However, this phenomenon did not appear in quarter-point loading conditions.

(4) Based on the interaction formula proposed in current standards for timber structures, an equivalent beam-column method was introduced to estimate the loading capacity of laminated timber arches subjected to vertical concentrated loads. The design formulas in NDS can be used to evaluate the loading capacity of glulam arches with acceptable accuracy. The moment amplification factor provided in NDS was recommended to integrate the second-order effect.

\section{Conflicts of Interest}

The authors declare that they have no conflicts of interest.

\section{Acknowledgments}

This research was funded by the National Natural Science Foundation of China (Nos. 51778069, 51978081 and 51578554), the Horizon 2020 Marie Skłodowska-Curie Individual Fellowship of European Commission (Grant no. 793787), the Hunan Provincial Innovation Foundation for Postgraduate, China (No. CX20190656), and the Special Funds for Scientific Research in Public Welfare Industries of China Forestry Administration (Grant no. 201304504).

\section{References}

[1] H. Yang, D. Ju, W. Liu, and W. Lu, "Prestressed glulam beams reinforced with CFRP bars," Construction and Building Materials, vol. 109, pp. 73-83, 2016.

[2] D. Michael and P. Dave, "Engineered timber and structural form in sustainable design," Construction Materials, vol. 168, no. 4, pp. 161-172, 2015.

[3] M. Cepelka and K. A. Malo, "Moment resisting on-site splice of large glulam elements by use of mechanically coupled long threaded rods," Engineering Structures, vol. 163, pp. 347-357, 2018.

[4] A. W. Ostrycharczyk and K. A. Malo, "Parametric study on effects of load position on the stress distribution in network arch timber bridges with light timber decks on transverse crossbeams," Engineering Structures, vol. 163, pp. 112-121, 2018.

[5] J. Murnieks, D. Serdjuks, and K. Buka-Vaivade, "Load-carrying capacity increase of arch-type timber roof," in Proceedings of the 12th International Scientific and Practical Conference, vol. 1, pp. 175-179, Rezekne, Latvia, June 2019.
[6] R. Crocetti, J. M. Branco, and J. F. Barros, "Timber arch bridges with V-shaped hangers," Structural Engineering International, vol. 29, no. 2, pp. 261-267, 2019.

[7] U. Rodman, M. Saje, I. Planinc et al., "The lateral buckling of timber arches," International Journal of Structural Stability and Dynamics, vol. 13, no. 8, 2013.

[8] E. Zhu and H. Zhou, "Creep buckling of glulam arches," Journal of Shenyang Jianzhu University (Natural Science), vol. 25, no. 4, pp. 640-655, 2009, in Chinese.

[9] B. Kasal and R. Blass, "Experimental and analytical investigation of crack development in composite reinforced laminated arch," Materials and Structures, vol. 46, no. 1-2, pp. 173-180, 2013.

[10] J. Jönsson, "Load carrying capacity of curved glulam beams reinforced with self-tapping screws," Holz als Roh- und Werkstoff, vol. 63, no. 5, pp. 342-346, 2005.

[11] A. Kukule and K. Rocens, "Reduction of wood consumption for glulam arch by its strengthening,"in Proceedings of theInternational Conference on Innovative Materials, Structuresand Technologies, Riga, Latvia, vol. 12, pp. 69-76, 2014.

[12] N. Olsson, "Reliability and optimization of timber arches," Master's thesis, Lulea University of Technology, Luleå, Sweden, 1997.

[13] A. Kánnár, Z. Karácsonyi, K. Andor, and L. Csóka, “Analysis of glued-laminated timber structure during five years of outdoor operation," Construction and Building Materials, vol. 205, pp. 31-38, 2019.

[14] D. Rammer and P. Line, "Lateral testing of glued laminated timber tudor arch," in Proceedings of the 2016 World Conference on Timber Engineering, Vienna, Austria, August 2016.

[15] J. Wei, Q. Wu, B. Chen, and T.-L. Wang, "Equivalent beamcolumn method to estimate in-plane critical loads of parabolic fixed steel arches," Journal of Bridge Engineering, vol. 14, no. 5, pp. 346-354, 2009.

[16] GB/T 50708-2012, Standard for Test Methods of Timber Structures, China Architecture \& Building Press, Beijing, China, 2012.

[17] American Wood Council, National Design Specification for Wood Construction, American Wood Council (ACI), Leesburg, VA, USA, 2018.

[18] BS EN 1995-1-1:2004+A2:2014, Eurocode 5: Design of Timber Structures, Part 1-1: General-Common Rules and Rules for Buildings, European Committee for Standardization (CEN), Brussels, Belgium, 2014.

[19] GB 50005-2017, Standard for Design Timber Structures, China Architecture \& Building Press, Beijing, China, 2017.

[20] GB/T 50329-2012, Standard for Test Methods of Timber Structure, China Architecture \& Building Press, Beijing, China, 2012.

[21] R. C. Spoorenberg, H. H. Snijder, and J. C. D. Hoenderkamp, "A theoretical method for calculating the collapse load of steel circular arches,” Engineering Structures, vol. 38, pp. 89-103, 2011.

[22] H. Yang, W. Liu, W. Lu, S. Zhu, and Q. Geng, "Flexural behavior of FRP and steel reinforced glulam beams: experimental and theoretical evaluation," Construction and Building Materials, vol. 106, pp. 550-563, 2016.

[23] S. Huang, "A brief description of the design formula of timber members under compression and lateral loads in Chinese code," Journal of Building Structures, vol. 20, no. 3, pp. 50-57, 1999, in Chinese. 